\title{
Getting Married? Protect Your Business Venture With a Prenup
}

\author{
James Hoffman \\ Dwight Kealy (New Mexico State University)
}

KEYWORDS: Legal, Startups, Prenuptial Agreement, Risk.

A prenuptial agreement (prenup) is a legal contract between prospective spouses to modify the terms of their marriage that would otherwise be governed by state law. Although a prenup does not mean completely excluding a loved one from any interest in the entrepreneurial venture, it does mean the entrepreneur is in control of how much of a stake, if any, his or her future spouse has in their business.

\section{Having a prenuptial}

agreement

(http://www.wallackfirm.com/whatwedo/)

(http://www.wallackfirm.com/whatwedo/) in place before an entrepreneur gets married is a common way to reduce risk and complications in the event of a divorce. This article discusses the importance for an entrepreneur to have a well-thought-out prenuptial agreement in place that considers the venture and its current and potential value. (Note that the advice in this article is for unmarried people; married people who are considering starting a business can explore something similar, called a post-nuptial agreement. The rules and enforceability vary from state to state. And whether it's a post-nuptial or prenuptial, get legal help.)

\section{INTRODUCTION}

The primary goal for most entrepreneurial firms is to create and increase value. Businesses create and increase value by increasing revenue while simultaneously managing costs and risk. One threat facing entrepreneurs is they focus so much on increasing revenue and (to a lesser degree) managing costs that they ignore managing risk. While risk can take on many forms, decisions made in an entrepreneur's personal life can greatly increase risk to the firm.

That's why it's important for an entrepreneur to have a well-thought-out prenup in place before getting married. This is especially important because the divorce rate in the United States is around 45\% (U.S. Census Bureau, 2022) while data from the Bureau of Labor Statistics shows that approximately $20 \%$ of new businesses fail during the first two years of being open, $45 \%$ during the first five years, and $65 \%$ during the first 10 years. Only $25 \%$ of new businesses make it to 15 years or more.

\section{HOW A DIVORCE CAN PUT AN ENTREPRENEUR'S BUSINESS AT RISK}

Being an entrepreneur is a rewarding experience, and most entrepreneurs put everything they have into seeing their business come to life and grow. However, it is also a risky endeavor. A successful entrepreneurial venture is an asset and, in many cases, can be a huge asset. However, it can often be tricky for the entrepreneur to manage their business when they have a spouse who may or may not contribute to the entrepreneurial venture (Louis, 2022).

Because of this, entrepreneurs need to keep in mind that it's not guaranteed that an endeavor will be successful in the future, whether that endeavor is a business or a marriage. That's why it is wise for entrepreneurs to protect themselves before making a commitment (The Wallack Firm, P.C. (https://www.wallackfirm.com/)

(https://www.wallackfirm.com/)

(https://www.wallackfirm.com/)

(https://www.wallackfirm.com/)

(https://www.wallackfirm.com/) , 2021). It is also important for entrepreneurs to understand that if the marriage is not successful and ends in divorce, most states give judges discretion to divide marital assets equitably, which usually involves considering the length of the marriage, the contribution to acquiring the assets, and each spouse's financial condition. Such a scenario could have a crippling effect on a business for many 
reasons.

\section{WHY ENTREPRENEURS SHOULD HAVE A PRENUPTIAL AGREEMENT}

Minimizing risk. While many entrepreneurs may not be deterred by the risk of not having a prenup, minimizing the risk can make it easier to plan ahead and navigate difficult situations. Having a prenuptial agreement(http://www.wallackfirm.com/whatwedo/)

(http://www.wallackfirm.com/whatwedo/) before an entrepreneur gets married is a common way to reduce risk and complications in the event of an unexpected divorce (The Wallack Firm, P.C. (https://www.wallackfirm.com/)

(https://www.wallackfirm.com/)

(https://www.wallackfirm.com/)

(https://www.wallackfirm.com/)

(https://www.wallackfirm.com/) , 2021).

Transparency. With a thoughtfully drafted prenuptial, prospective spouses enter marriage knowing what will happen to property in the case of divorce or death (Hughes,

Massenzio

(https://onlinelibrary.wiley.com/action/doSearch?Contrib AuthorRaw=Massenzio\%2C+Susan+E) \& Whitaker (https://onlinelibrary.wiley.com/action/doSearch?Contrib AuthorRaw=Whitaker\%2C+Keith) , 2017). In many ways a prenup can help prevent a nasty divorce and may even strengthen the entrepreneur's marriage.

The entrepreneur's ideas. Ideas, inventions and other creations of the mind are intellectual property. In many cases an entrepreneur may have considerable intellectual property, even if it has yet to be fully realized. Establishing ownership of intellectual property in a prenuptial agreement can allow entrepreneurs to retain control of it in a divorce. It can also help them secure any financial profits they earn from it in the future (The Wallack Firm, P.C.(https://www.wallackfirm.com/) (https://www.wallackfirm.com/)

(https://www.wallackfirm.com/)

(https://www.wallackfirm.com/)

(https://www.wallackfirm.com/) , 2021).

Business Ownership. Entrepreneurs can have a stake in one or several business ventures before they get married. If their marriage ends someday, their role in these companies - and the companies themselves could be in jeopardy. For example, they could wind up having to split any appreciation in the value of the business with an ex-spouse, and if they own a business with their soon-to-be spouse, they risk serious consequences if they do not address ownership and business division in the event of a divorce in a prenup (The Wallack Firm, P.C.(https://www.wallackfirm.com/) (https://www.wallackfirm.com/) (https://www.wallackfirm.com/) (https://www.wallackfirm.com/) (https://www.wallackfirm.com/) , 2021).

Property. Entrepreneurs often enter a marriage with separate assets and property. These properties (and profits from these properties) can become eligible for division in a divorce if they are not protected in a prenuptial agreement. It also puts business property at risk if the entrepreneur's spouse carries debt and creditors come after the entrepreneur for payment. Additionally, a divorce could wind up costing the business money and drain resources, which would adversely affect employees and business partners (The Wallack Firm, P.C.(https://www.wallackfirm.com/) (https://www.wallackfirm.com/)

(https://www.wallackfirm.com/)

(https://www.wallackfirm.com/)

(https://www.wallackfirm.com/) , 2021).

Many Partnership Agreements Require Prenups. Many savvy entrepreneurs know the drawbacks of having a partner go through a divorce. They want their partners to be the people they contracted with as opposed to the spouses of those people. Many entrepreneurs and their attorneys will insist on a prenup clause in a partnership agreement. This typically includes language requiring every married person in the partnership to have a prenup in place protecting the business from division in the divorce. This is also a great way to get a future spouse to be more accepting of the agreement. It makes it a little less personal since it's something required for everyone (Louis, 2022).

Maintaining Control. Another reason to have a prenup is to maintain control over who has a say in the business. An entrepreneur probably doesn't want their ex having a say in how the business is run, especially if the ex-spouse has never been a part of the business. A prenup can protect the entrepreneur from that possibility.

Keeping the Business in the Family. Often family businesses have prenup requirements to keep the business in the family, thus blocking an ex-family 
member from having an interest or say in the business the family started. However, if a spouse works in the business, a clause might specify that after so many years of marriage the spouse can be entitled to a share.

Mitigating Support. A prenup is a great tool to control the amount of spousal support the entrepreneur may be obligated to pay. This does not mean providing no support to a spouse who is entitled to it, but it does mean being able to limit the amount of support so both spouses know what to expect and can plan and prepare for their financial future in the event of a divorce.

Avoiding Forced Liquidation. In a divorce, entrepreneurs who cannot afford to buy out a spouse may have no other option than to liquidate the business. If they have no other options or way to pay the soon to be ex-spouse for the spouse's share, then they may have to sell the business and use the proceeds for the buyout. To prevent this scenario, an entrepreneur's best bet is to have a prenup that either retains the business as separate property or specifies the percentage of the business that will go to their spouse and how the spouse will receive it (such as giving the spouse other assets or setting up a payment schedule).

\section{WHAT SHOULD BE INCLUDED IN THE PRENUP}

Once a decision is made to have a prenuptial agreement, it is critical that the prenup is structured in a manner that maximizes protecting the entrepreneurial venture. Below are some of the key things entrepreneurs should consider including in a prenuptial agreement. However, their level of importance and how they are applied may depend on whether the entrepreneur lives in a community property or a common law property state.

\section{Treatment of Business Appreciation as Separate} Pre-Marital Property. Prenuptial agreements are contracts between couples that classify premarital assets as either separate or marital. An enforceable prenup(https://legaltemplates.net/form/prenuptial-

agreement/) allows the entrepreneur and spouse to agree on which assets will remain as pre-marital, thus exempting these assets from splitting any increase in value. Characterizing the entrepreneurial venture as a separate property helps prevent an entrepreneur's spouse from taking 50 percent of the business's appreciated value. Thus, when discussing the prenup, an entrepreneur needs to make sure to include a provision that addresses the appreciation of not only the business, but also all other pre-marital assets.

Limitation of Debt Liability. As mentioned earlier, debt can be a complicated aspect of divorces. Depending on the state where the entrepreneur lives, he or she may be on the hook for debt that a spouse incurred alone. For instance, if the debt was used to acquire something that could be considered beneficial to the marriage, then it may be seen as shared debt (http://twocents.lifehacker.com/how-to-protect-yourcredit-when-you-marry-into-debt-1576458795)

between the married couple. Thus, in states that have this law, entrepreneurs should add a provision to the prenup that specifies that the entrepreneur and spouse agree not to assume each other's debts throughout the marriage. Additionally, the prenup should also clarify how debt incurred by the married couple will be divided.

Create a Partnership or Operating Agreement. If the entrepreneur is not the sole owner of the business, then he or she may also want to consider having their business partners sign a prenup. It has become quite common for partnerships and operating agreements to require that unmarried shareholders get a prenuptial agreement

(http://www.inc.com/guides/2010/05/protecting-yourbusiness-from-divorce.html) before marriage. These sorts of agreements usually require the shareholders' spouses to sign a waiver of their interests in the business and a provision that stipulates that any transfer of share to the spouse must first be approved by all shareholders.

The Importance of Business Records. To strengthen the prenup, it's essential that an entrepreneur has accurate records of their business's transactions before and during the marriage.

These records will help to establish the entrepreneur's earning capacity before the marriage and justify why the value of the business should be considered a separate asset. Additionally, having well-kept balance sheets will also help prove to the judge that the entrepreneur's marital property never intermingled with the business

Establish the Value of the Business as of the Date of the Marriage. While additional value gained during the marriage may be subject to division, an entrepreneur can, as the titled owner, protect the 
premarital value of the business as his or her separate property so that it will not be subject to any type of distribution upon divorce. Additionally, including an agreement as to how the business will be valued at the time of divorce could save an entrepreneur the expense and disruption of an intrusive third-party valuation process. This makes demands on employees, accountants and others associated with the business, as people come on-site to evaluate financial records, practices and procedures.

\section{Appreciation or Depreciation of the Business from} the Date of Marriage. Will the entrepreneur's spouse share in the company's profits and losses? To figure this out, consider the level of direct or indirect contributions the spouse will be making to the company, and whether he or she has invested capital in the business. Set clear expectations for what the spouse will contribute to the business, and make sure he or she is compensated fairly for working in the business. The reason for this is often during divorce, a spouse will claim that he or she acted in a certain capacity but was not fairly compensated, and therefore deserves a larger percentage of the business. However, if he or she was drawing a market-appropriate salary, then their entitlement to a greater share is either eliminated or minimized. Likewise, the entrepreneur should agree to how a spouse's indirect contribution is valued; for example, if he or she stays home to raise the children so that the entrepreneur can run and grow the business.

Source of Capital. Determine exactly where capital for the business will come from if needed. Will these funds come out of marital property? If so, will the entire business then become marital property, or will the marital estate get a credit back for the capital that was contributed?

\section{Specify a Percentage. Specify a percentage of the business your spouse will be entitled to in the event of divorce. Assigning a percentage can prevent the business from being subject to the same distribution guidelines as other marital assets. For example, if you have agreed that he or she will receive $10 \%$ of the value of your interest in the company, then that is the percentage he or she will receive upon divorce, even if other marital assets are being divided 50/50.}

Income. Details of how the entrepreneur's income will be handled need to be included. Some entrepreneurs opt not to take a market-appropriate salary for work in the business, choosing instead to keep those funds in the business. This limits their capacity for creating marital property-savings, for example-that could be shared with their spouse upon divorce. A prenup gives the entrepreneur an opportunity to address this if a divorce takes place. As with other related issues, the entrepreneur will want to ensure a fair distribution of assets (Frawley \& Pollock (https://www.forbes.com/sites/frawleypollock/) (https://www.forbes.com/sites/frawleypollock/) , 2019).

\section{LIMITATIONS OF PRENUPTIAL AGREEMENTS}

Although a prenuptial agreement can be a useful tool to protect an entrepreneur's business from a bad divorce, they have some limitations. For example, some couples make the mistake of drafting a prenuptial agreement with the same lawyer or without the spouse having his or her own counsel. This can weaken the enforceability of the agreement and may even void it completely.

A prenup can also be limited if the entrepreneur's spouse contributed time or money to the company during the marriage. This article is based on the premise that one spouse is the entrepreneur and the other spouse makes limited contributions to the business. However, if the other spouse becomes a coentrepreneur and makes major contributions to the business, then the prenuptial agreement will need to be modified, given any contribution the other spouse makes may end up changing a portion of the business to a marital asset. Similarly, if any marital finances were used towards the business, a prenuptial agreement will hold less weight.

\section{CONCLUSIONS}

Marriage requires partners to deal with the pragmatic as well as the romantic, so talking about business and financial matters should be a natural part of premarital discussions. A prenup gives entrepreneurs the opportunity to put a plan in place that, hopefully, they will never need (Frawley \& Pollock (https://www.forbes.com/sites/frawleypollock/)

(https://www.forbes.com/sites/frawleypollock/) , 2019). The biggest hurdle for most entrepreneurs moving forward with a prenuptial agreement is discussing with their future spouse whether their business should be separate or marital property. While a decade or so ago asking one's future spouse for a prenuptial agreement might have been viewed in a negative light, over the 
past several years prenuptial agreements have become more commonplace, as couples increasingly recognize the wisdom of having a legally binding contract outlining, for instance, who owns what prior to the marriage, and how marital assets will be distributed in the event of divorce.

To make the conversation about a prenuptial agreement easier, an entrepreneur should highlight to their future spouse that discussing a prenuptial agreement can identify sticking points that they can resolve them before getting married (Louis, 2022), and that while neither of them wants to think that their marriage might end in divorce, having a prenup in place can give them peace of mind, especially with business and personal factors at stake.

A prenup also opens the door for some interesting planning opportunities. For example, instead of just thinking the prenup is a great way to keep from sharing great potential rewards with a spouse, it could be viewed as a great way for the entrepreneur to take greater risks. New business ventures often fail, and maybe the entrepreneur and non-entrepreneur spouse could see the benefit of keeping assets separate, knowing that if the venture fails, the entrepreneur spouse can declare personal bankruptcy to discharge all business debts while the other spouse retains separate capital for future endeavors. It's interesting to consider how prenups could benefit both parties. Additionally, having a prenup will also help them avoid a contentious or expensive divorce, where in the end no one makes money except for the attorneys.

Overall, it is hoped this article sheds light on why it makes so much sense for entrepreneurs to create a plan with their future spouse now that determines what will happen to the company and who has rights to which assets. It is also hoped that this article provides guidance on what should be included in a prenuptial agreement, so an entrepreneur's business does not become marital property, subject to distribution by the courts in the event of divorce.

\section{REFERENCES}

Hughes Jr, J. E., Massenzio, S. E., \& Whitaker, K. (2017). Complete Family Wealth. John Wiley \& Sons.

Joleena Louis Law, 17 Aug. 2020, https://www.joleenalouislaw.com/blog/10-reasons-whyentrepreneurs-must-have-a-prenup?utm_campaign=8-r easons-why-entrepreneurs-must-have-a-prenup

U.S. Bureau of Labor Statistics, 2022, Entrepreneurship and the U.S. Economy (bls.gov) (https://www.bls.gov/bdm/entrepreneurship/entrepreneu rship.htm)

U.S. Census Bureau, 2022, U.S. Marriage and Divorce Rates Declined in Last 10 Years (census.gov) (https://www.census.gov/library/stories/2020/12/unitedstates-marriage-and-divorce-rates-declinedlast-10-years.html)

The Wallack Law Firm, 22 Dec. 2021, https://www.wallackfirm.com/blog/2021/12/how-canprenuptial-agreements-benefit-you/ 